\title{
The Interdependency of the Morphological Variations of the Planktonic Foraminiferal Species Globigerina bulloides in Surface Sediments on the Environmental Parameters of the Southwestern Indian Ocean
}

\author{
Abhijit Mazumder, ${ }^{1}$ Neloy Khare, ${ }^{2}$ and Pawan Govil ${ }^{1}$ \\ ${ }^{1}$ Birbal Sahni Institute of Palaeobotany, 53 University Road, Lucknow 226 007, India \\ ${ }^{2}$ Ministry of Earth Sciences, Prithvi Bhawan, Near India Habitat Centre, Lodhi Road, New Delhi 110 003, India \\ Correspondence should be addressed to Abhijit Mazumder; abhijit_mazumder@bsip.res.in
}

Received 21 March 2014; Revised 13 September 2014; Accepted 25 September 2014; Published 29 October 2014

Academic Editor: Alessandra Asioli

Copyright (C) 2014 Abhijit Mazumder et al. This is an open access article distributed under the Creative Commons Attribution License, which permits unrestricted use, distribution, and reproduction in any medium, provided the original work is properly cited.

18 surface sediment samples collected from a north-south transect along the Indian Ocean have been analyzed for planktonic Foraminifera content. Among the other planktonic foraminiferal faunas, Globigerina bulloides was present substantially in all samples. Census data of G. bulloides were measured for different parameters (average size, mean proloculus size, coiling direction, and number of chambers) and a Q-mode cluster analysis was applied on these data. Samples were segregated into two homogeneous clusters, each reflecting particular environmental conditions. Two clusters are as follows: (1) Cluster A, comprised of 6 samples and characterized by the highest range of foraminiferal and ecological parameters, except sea surface temperature and salinity which shows the lowest range, and (2) Cluster B, comprised of 12 samples and characterized by the lowest range of foraminiferal parameters and ecological parameters, except sea surface temperature and salinity which shows the highest range. The study suggests that the ecological parameters are the governing factors for the morphological characteristics of planktonic foraminiferal species $G$. bulloides.

\section{Introduction}

Morphological variations of planktic Foraminifera have been extensively used to decipher paleoclimatic, paleoenvironmental, and paleoecological reconstructions [1-3].

Globigerina bulloides d'Orbigny, a spinose planktic foraminifer, is substantially present in temperate to subpolar water masses and is also characteristic of upwelling areas in lower latitudes [4-11]. In these upwelling regions, G. bulloides contributes maximum foraminiferal flux to the ocean floor $[12,13]$ and therefore provides important geochemical information for paleoceanographic studies [14-17].

Although earlier workers [18-21] discussed the general distribution of G. bulloides in Indian Ocean surface waters and sediments along with its relation to the change of ecological parameters, no attempt was made to study the morphological variations of this planktic foraminiferal species along a north-south transect in the Indian Ocean region in connection with the ecological parameters.

In the present work, the results of a biometric study of the latitudinal variation in test size, proloculus size, number of chambers, and coiling direction of G. bulloides from the surface sediments of a north-south transect of the Indian Ocean were analyzed. The major objective of this study is to link the patterns of morphological variation with the changes in physicochemical properties of the surface water in order to comprehend the ecological control on morphological characteristics in G. bulloides in the modern marine environment.

\section{Study Area}

The study area falls within the southwestern Indian Ocean basin. Previously, Ichiye [22], Wyrtki [23], and Gordon [24] gave a detailed account of the physical oceanography of 


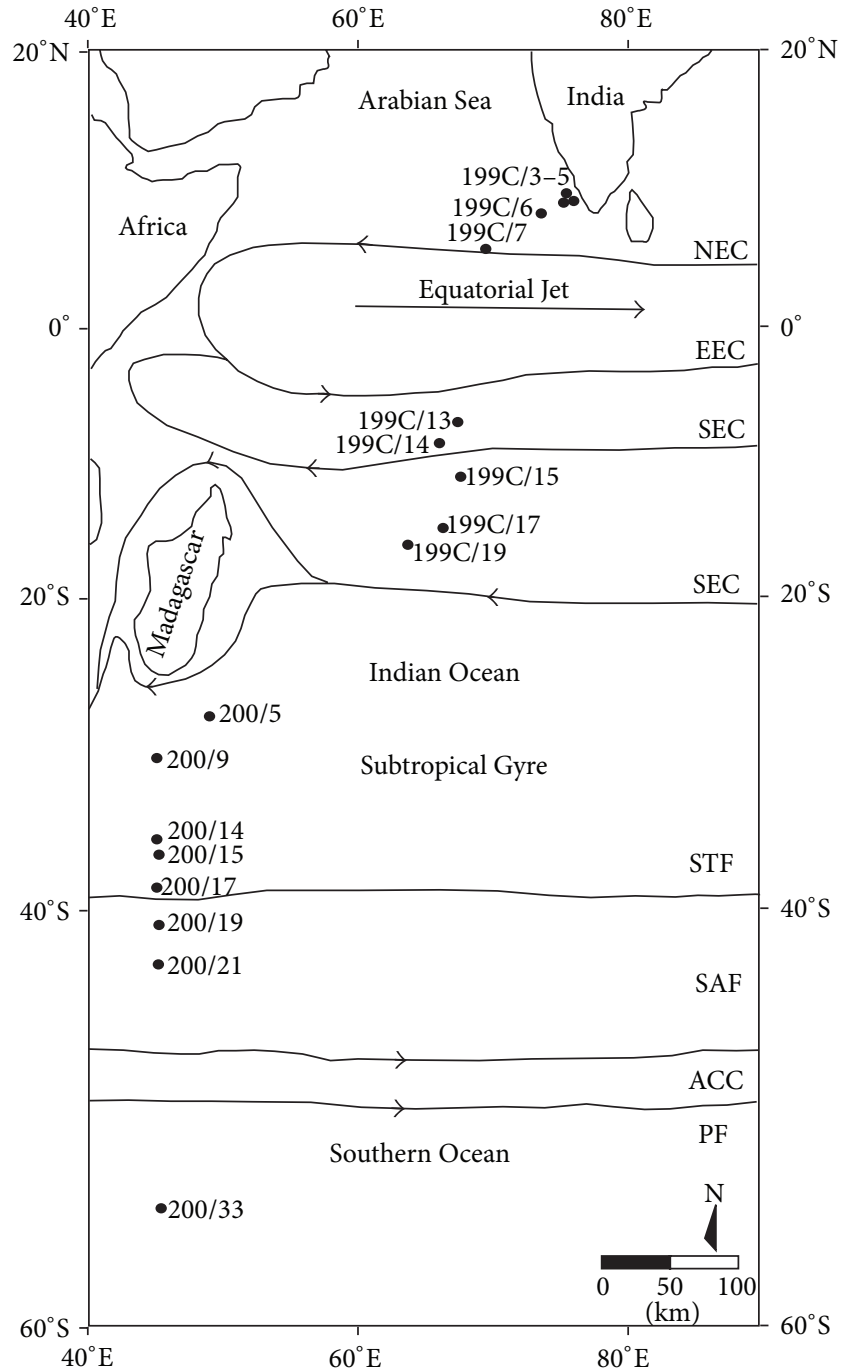

FIGURE 1: Location of sampling stations along a north-south transect in the southwestern Indian Ocean (NEC: North Equatorial Current; EEC: Eastward Equatorial Current; SEC: South Equatorial Current; STF: Subtropical Front; SAF: Subantarctic Front; ACC: Antarctic Circumpolar Current; PF: Polar Front).

the southern Indian Ocean. Two critical water-mass boundaries are present in this area: the Antarctic Polar Front, which separates Antarctic water mass from Subantarctic water mass, and the Subtropical Convergence, which separates Subantarctic from subtropical water masses (Figure 1). The Antarctic Convergence exhibits the sharpest water-mass boundary in the southern Indian Ocean waters in terms of the change in temperature and salinity whereas the gradients at the Subtropical Convergence $\left(38^{\circ} \mathrm{S}-40^{\circ} \mathrm{S}\right)$ are less steep.

During the pilot expedition to the Southern Ocean (PESO) aboard the Oceanic Research Vessel Sagar Kanya (199C and 200th cruises), a total of 18 surface sediment samples $(0-1 \mathrm{~cm})$ (including core top and grab samples) were collected along a north-south transect between $9.50^{\circ} \mathrm{N}$ to $45^{\circ} \mathrm{S}$ latitude and $80^{\circ} \mathrm{E}$ to $40^{\circ} \mathrm{E}$ longitude, covering tropical, subtropical, and Subantarctic waters in the southwestern
Indian Ocean to undertake planktonic foraminiferal analysis (Figure 1, Table 1).

\section{Hydrologic Setting}

The sampling stations are characterized by several distinct water regions spreading over latitudinal segments: tropical, subtropical, transitional, and Subantarctic. They are divided into these waterbodies depending upon several zoogeographic provinces which are mainly influenced by ecological and climatological parameters $[4,25]$. Southern Ocean can be divided into three prominent zones based on the water dynamics: the Western Boundary Current (WBC) zone (between $35^{\circ}$ and $45^{\circ} \mathrm{S}$ ), the Antarctic Circumpolar Current (ACC) zone (between $45^{\circ}$ and $60^{\circ} \mathrm{S}$ ), and the Seasonal Sea Ice (SSI) zone (between $60^{\circ}$ and $75^{\circ} \mathrm{S}$ ). The WBC zone comprises of mainly three currents at western boundary; they are the Agulhas Current, the Brazil/Malvinas Current, and the East Australia Current. Hydrographic conditions in Southern Ocean (SO) are mainly controlled by an eastward flowing Antarctic Circumpolar Current (ACC) [26].

The western part of the southern Indian Ocean acquires heat from the warm western boundary current [27]. The available data on the hydrological fronts and freshwater input along $62^{\circ} \mathrm{E}$ and $30^{\circ} \mathrm{E}$ sections [28] highlighted that the areas west of the Crozet Plateau and east of the KerguelenAmsterdam passage are two vital regions where the fronts diverse and converse. Agulhas Return Front (ARF), Southern Subtropical Front (SSTF), and Northern Subantarctic Front (NSAF) were designated as the combined front between $40^{\circ} 15^{\prime} \mathrm{S}$ and $43^{\circ} \mathrm{S}$ suggesting that the combined isotherms exhibit temperature variation from $19^{\circ} \mathrm{C}$ to $10^{\circ} \mathrm{C}$ and the combined isohalines exhibit a drop in salinity from 35.54 to $34.11 \mathrm{psu}$ across $\sim 3^{\circ}$ latitude [26].

The Southern Subantarctic Front is situated between $47^{\circ}$ and $48^{\circ} \mathrm{S}$ (between 6 and $7^{\circ} \mathrm{C}$ isotherms). The Polar Front (PF1) is present between $49^{\circ}$ and $50^{\circ} \mathrm{S}$ (isotherms varied from 5 to $4^{\circ} \mathrm{C}$ ). Southern Polar Front (PF2) is present between $52^{\circ}$ and $54^{\circ} \mathrm{S}$ (temperature range $3-2^{\circ} \mathrm{C}$ ). Antarctica Intermediate Water (AAIW) flows at $\sim 1150$ and $\sim 1200 \mathrm{~m}$ water depth and the characteristics of this water mass were recorded as temperature of $\sim 4.4^{\circ} \mathrm{C}$, minimum salinity of $\sim 34.42 \mathrm{psu}$, and density of $\sim 27.24 \mathrm{~kg} \mathrm{~m}^{-3}$ in the northern front of subtropical zone [29].

Circumpolar Deep Water is characterized by different features, such as temperature of $\sim 2^{\circ} \mathrm{C}$, salinity of $\sim 34.77 \mathrm{psu}$, and density of $\sim 27.8 \mathrm{~kg} \mathrm{~m}^{-3}$. It flows at the water depth between 2000 and $3800 \mathrm{~m}$ north of $45^{\circ} \mathrm{S}$ and rises sharply to shallower depths south of the frontal zone. North Atlantic Deep Water (NADW) with higher salinities ( 34.8 psu) transported from the South Atlantic to the southwestern corner of the Indian Ocean and Madagascar ridge blocks NADW to reach east of $\sim 45^{\circ} \mathrm{E}$ [30]. Below the CDW, temperature and salinity decrease due to the influence of Antarctica Bottom Water (AABW). AABW is recorded between $49^{\circ}$ and $56^{\circ} \mathrm{S}$ at the depth of 4100 to $4700 \mathrm{~m}$ with a temperature of $\sim-0.165$ to $-0.62^{\circ} \mathrm{C}$, salinity of $\sim 34.67$ to $34.65 \mathrm{psu}$, and density of $\sim 27.85$ to $27.86 \mathrm{~kg} \mathrm{~m}^{-3}$ [26]. The Antarctic Circumpolar Current (ACC) reaches the ocean floor to mix with the North Atlantic 
TABLE 1: Average values (mean as open values and range in parenthesis) of the morphological parameters of G. bulloides for each sampling location.

\begin{tabular}{|c|c|c|c|c|c|}
\hline Sample number & Latitude & $\begin{array}{c}\text { Test size }(\mu \mathrm{m}) \\
\text { [range] }\end{array}$ & $\begin{array}{l}\text { MPS }(\mu \mathrm{m}) \\
\text { [range] }\end{array}$ & $\begin{array}{c}\text { Number of } \\
\text { chambers } \\
\text { [range] }\end{array}$ & Dextral \% \\
\hline SK199C/3 & 9.5045 & $\begin{array}{c}268.00 \\
{[192-348]}\end{array}$ & $\begin{array}{c}8.56 \\
{[6-12]}\end{array}$ & $\begin{array}{c}10.33 \\
{[9-12]}\end{array}$ & 73.33 \\
\hline SK199C/4 & 9.4051 & $\begin{array}{c}336.82 \\
{[260-442]}\end{array}$ & $\begin{array}{c}15.72 \\
{[10.4-6]}\end{array}$ & $\begin{array}{l}10.64 \\
{[9-12]}\end{array}$ & 54.54 \\
\hline SK199C/5 & 8.9917 & $\begin{array}{c}241.50 \\
{[180-324]}\end{array}$ & $\begin{array}{c}9.15 \\
{[6-18]}\end{array}$ & $\begin{array}{c}9.63 \\
{[8-12]}\end{array}$ & 87.50 \\
\hline SK199C/6 & 8.1333 & $\begin{array}{c}347.90 \\
{[260-429]}\end{array}$ & $\begin{array}{c}14.55 \\
{[13-26]}\end{array}$ & $\begin{array}{l}10.48 \\
{[8-13]}\end{array}$ & 66.66 \\
\hline SK199C/7 & 5.5121 & $\begin{array}{c}233.33 \\
{[204-276]}\end{array}$ & $\begin{array}{c}7.07 \\
{[6-12]}\end{array}$ & $\begin{array}{c}10.11 \\
{[9-14]}\end{array}$ & 88.88 \\
\hline SK199C/13 & -7.3648 & $\begin{array}{c}260.14 \\
{[216-312]}\end{array}$ & $\begin{array}{c}8.99 \\
{[6-18]}\end{array}$ & $\begin{array}{c}10.71 \\
{[9-13]}\end{array}$ & 57.14 \\
\hline SK199C/14 & -9.1790 & $\begin{array}{c}243.20 \\
{[204-312]}\end{array}$ & $\begin{array}{c}8.64 \\
{[6-18]}\end{array}$ & $\begin{array}{c}10.40 \\
{[8-13]}\end{array}$ & 60.00 \\
\hline SK199C/15 & -11.4243 & $\begin{array}{c}238.00 \\
{[156-325]}\end{array}$ & $\begin{array}{c}7.47 \\
{[6-13]}\end{array}$ & $\begin{array}{c}9.80 \\
{[8-12]}\end{array}$ & 80.00 \\
\hline SK199C/17 & -15.2785 & $\begin{array}{c}225.35 \\
{[156-336]}\end{array}$ & $\begin{array}{c}7.96 \\
{[6-13]}\end{array}$ & $\begin{array}{c}11.10 \\
{[8-14]}\end{array}$ & 50.00 \\
\hline SK199C/19 & -16.2677 & $\begin{array}{c}245.05 \\
{[182-312]}\end{array}$ & $\begin{array}{c}8.13 \\
{[6.5-13]}\end{array}$ & $\begin{array}{c}10.05 \\
{[8-13]}\end{array}$ & 55.00 \\
\hline SK200/5 & -28.3215 & $\begin{array}{c}238.52 \\
{[156-312]}\end{array}$ & $\begin{array}{c}8.20 \\
{[6.5-13]}\end{array}$ & $\begin{array}{c}10.61 \\
{[9-12]}\end{array}$ & 52.17 \\
\hline SK200/9 & -30.9142 & $\begin{array}{c}271.00 \\
{[195-442]}\end{array}$ & $\begin{array}{c}9.40 \\
{[6.5-26]}\end{array}$ & $\begin{array}{c}10.62 \\
{[8-12]}\end{array}$ & 53.84 \\
\hline SK200/14 & -36.1217 & $\begin{array}{c}383.19 \\
{[257.1-485.7]}\end{array}$ & $\begin{array}{c}11.89 \\
{[7.1-21.4]}\end{array}$ & $\begin{array}{c}10.12 \\
{[8-12]}\end{array}$ & 73.53 \\
\hline SK200/15 & -37.0000 & $\begin{array}{c}259.50 \\
{[180-348]}\end{array}$ & $\begin{array}{c}9.15 \\
{[6-18]}\end{array}$ & $\begin{array}{c}9.79 \\
{[8-13]}\end{array}$ & 75.00 \\
\hline SK200/17 & -39.0285 & $\begin{array}{c}248.25 \\
{[192-336]}\end{array}$ & $\begin{array}{c}7.43 \\
{[6-18]}\end{array}$ & $\begin{array}{c}9.38 \\
{[8-10]}\end{array}$ & 75.00 \\
\hline SK200/19 & -40.9813 & $\begin{array}{c}363.05 \\
{[192-520]}\end{array}$ & $\begin{array}{c}16.55 \\
{[6-26]}\end{array}$ & $\begin{array}{c}10.24 \\
{[8-12]}\end{array}$ & 76.19 \\
\hline SK200/21 & -43.1500 & $\begin{array}{c}352.73 \\
{[273-416]}\end{array}$ & $\begin{array}{c}16.73 \\
{[10.4-26]}\end{array}$ & $\begin{array}{c}10.33 \\
{[8-13]}\end{array}$ & 86.66 \\
\hline SK200/33 & -55.0065 & $\begin{array}{c}360.29 \\
{[260-520]}\end{array}$ & $\begin{array}{c}15.69 \\
{[20.4-26]}\end{array}$ & $\begin{array}{c}9.57 \\
{[8-12]}\end{array}$ & 64.28 \\
\hline
\end{tabular}

Deep Water (NADW) as well as deep waters from the Indian Ocean and the Pacific Ocean. Thus, the mixture of these deep waters along with the Circumpolar Deep Waters (CDW) spreads to other oceans basins.

AABW and CDW enter the Indian Ocean in the west around Madagascar and East Africa and in the east along the Ninety East Ridge [31]. A very strong and deep overturning cell about $1800 \mathrm{~m}$ below near $32^{\circ} \mathrm{S}$ carries layers of warm nearsurface water and cold deep water in opposite directions [30]. The Southern Ocean has also a unique role in the global scale overturning circulation caused by the circumpolar connection in the Southern Ocean. Water found at intermediate and abyssal depths at low latitudes rises towards the surface in the Southern Ocean. Deep water that upwells closer to Antarctica loses its heat after coming in contact with the cold air blowing off the continent and its salinity is eventually increased by brine released during sea ice formation. The dense water formed in this process gradually sinks near the continental margin of Antarctica and takes a return path to the north in deep currents flowing along the sea floor.

\section{Methods}

All the sediment samples were processed as per standard procedures. An appropriate amount of sediment ( $\sim \mathrm{gm})$ from each sample was dried overnight at $45^{\circ} \mathrm{C}$. Dried sediment samples were soaked in water and subsequently treated with sodium hexametaphosphate in order to dissociate clay lumps. The treated sediments were sieved over $63 \mu \mathrm{m}$ sieve and dried and transferred to plastic vials. While processing the sediment samples, utmost care was taken to prevent any possible breaking of the foraminiferal test, by using extremely 
TABLE 2: Comparative morphological and ecological data for each cluster/subcluster for G. bulloides.

\begin{tabular}{|c|c|c|c|c|c|c|c|c|c|c|}
\hline \multirow[b]{2}{*}{ Clusters } & \multirow[b]{2}{*}{ Subclusters } & \multicolumn{4}{|c|}{ Morphological parameters } & \multicolumn{5}{|c|}{ Ecological parameters } \\
\hline & & $\begin{array}{l}\text { Avg. test } \\
\text { size }(\mu \mathrm{m})\end{array}$ & $\begin{array}{l}\text { Avg. MPS } \\
\quad(\mu \mathrm{m})\end{array}$ & $\begin{array}{c}\text { Avg. } \\
\text { number of } \\
\text { chambers }\end{array}$ & $\begin{array}{c}\text { Avg. } \\
\text { dextrality } \\
(\%)\end{array}$ & $\begin{array}{l}\text { Avg. } \\
\text { SST } \\
\left({ }^{\circ} \mathrm{C}\right) \\
\end{array}$ & $\begin{array}{l}\text { Avg. } \\
\text { SSS } \\
(\% o)\end{array}$ & $\begin{array}{l}\text { Avg. } \\
\text { nitrate } \\
\text { (psu) }\end{array}$ & $\begin{array}{l}\text { Avg. } \\
\text { phosphate } \\
\text { (psu) }\end{array}$ & $\begin{array}{c}\text { Avg. } \\
\text { dissolved } \\
\mathrm{O}_{2}(\mathrm{mg} / \mathrm{L})\end{array}$ \\
\hline A & & 357.33 & 15.19 & 10.23 & 70.31 & 14.61 & 34.77 & 4.14 & 4.07 & 5.34 \\
\hline B & & 247.65 & 8.34 & 10.21 & 67.32 & 20.55 & 35.03 & 1.89 & 2.39 & 4.82 \\
\hline & $\mathrm{B}_{1}$ & 238.03 & 8.23 & 10.54 & 54.29 & 21.27 & 35.08 & 0.48 & 1.68 & 4.71 \\
\hline & $\mathrm{B}_{2}$ & 240.27 & 7.78 & 9.73 & 82.85 & 21.11 & 34.77 & 0.58 & 3.10 & 4.87 \\
\hline & $\mathrm{B}_{3}$ & 264.66 & 9.02 & 10.36 & 64.83 & 19.27 & 35.23 & 4.29 & 2.56 & 4.90 \\
\hline
\end{tabular}

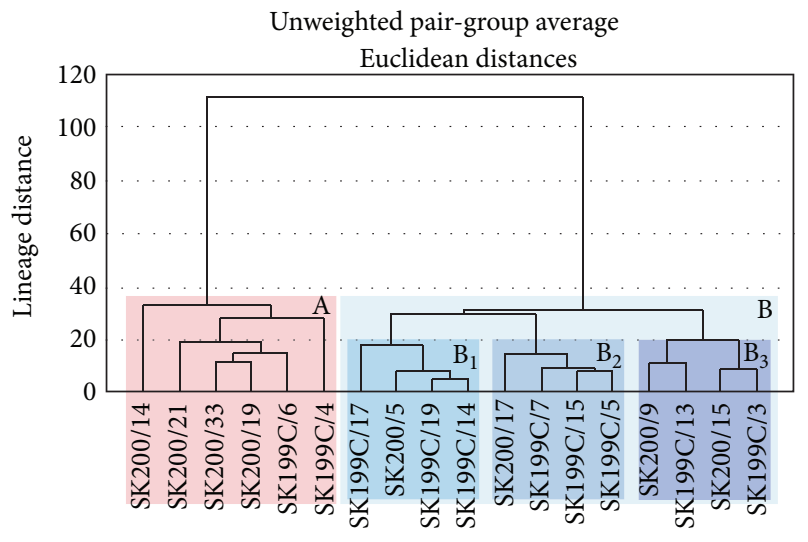

FIGURE 2: Results of the cluster analysis of the four morphological parameters (coiling direction, mean proloculus size (MPS), average test size, and number of chambers) analysed from the planktonic foraminiferal species Globigerina bulloides.

low water pressure for removing the finer $(>63 \mu \mathrm{m})$ fraction. The $>63 \mu \mathrm{m}$ fraction was dry sieved and, from the $>125 \mu \mathrm{m}$ fraction, an aliquot was taken by quartering and coning, to pick a minimum of 40 specimens of the planktic foraminiferal species $G$. bulloides.

After the picking procedure, morphological features such as coiling direction, shell size, number of chambers, and proloculus size were observed and measured under a stereo zoom microscope using a scale with divisions of $14 \mu \mathrm{m}$. The test size was measured along the last chamber to its diagonally opposite chamber through the apex; coiling direction was observed from dorsal side of the test, while the number of chambers was counted starting from the proloculus chamber to the last chamber observed on dorsal side of the test. The average values of these four parameters of all 40 individual specimens from each location were presented as mean values for each location (Table 1).

The data obtained was subjected to Q-mode cluster analysis. The analysis was performed using the unweighted pair group averaging method (Figure 2). The morphological parameters were chosen as variables to increase the precision of the analysis. The results of cluster analysis are plotted in the form of a two-dimensional hierarchy dendrogram wherein locations are presented along the $x$-axis while similarity level is plotted on $y$-axis (Figure 2). This dataset was compared with the modern hydrological settings (sea surface temperature, sea surface salinity, nutrients, and dissolved oxygen; mean values of $0 \mathrm{~m}, 50 \mathrm{~m}, 100 \mathrm{~m}, 150 \mathrm{~m}$, and $200 \mathrm{~m}$, considered the average value of $0-200 \mathrm{~m}$ water column) along the north-south transect in the present study area. This hydrological data was retrieved from World Ocean Atlas [32-35]. Moreover, the clusterwise comparative chart of morphological parameters and ecological parameters is tabulated to show the correlation between these two (Table 2).

\section{Results}

The Q-mode cluster analysis classified the samples into two homogeneous clusters (A and B) under the linkage distance 40 (Figure 2). Cluster $\mathrm{B}$ was in turn subdivided into subclusters $B_{1}, B_{2}$, and $B_{3}$ under the linkage distance 20 . Each cluster and subcluster is characterized by a particular association of ecological parameters. The following are the relation of clusters and subclusters with ecological parameters.

Cluster A comprises a total of 6 samples, of which two fall between the latitudes $9.4051^{\circ} \mathrm{N}$ and $8.1333^{\circ} \mathrm{N}$ (tropical zone) with the remaining samples within the latitudes $36.12^{\circ} \mathrm{S}$ and $45^{\circ} \mathrm{S}$ (towards the subpolar zone). This cluster is characterized by the highest range of all morphological characteristics: average test size (range 336.82-383.19 $\mu \mathrm{m}$; average $357.33 \mu \mathrm{m}$ ), mean proloculus size (range $11.89-16.73 \mu \mathrm{m}$; average $15.19 \mu \mathrm{m}$ ), number of chambers (range 9.57-10.64; average 10.23), and dextrality (range 54.54-76.19\%; average $70.31 \%$ ). Sea surface temperature (SST) and sea surface salinity (SSS) show the lowest range of values between $1.14-24.23^{\circ} \mathrm{C}$ (average 14.61) and 34.06-35.50 psu (average $34.77 \mathrm{psu}$ ), respectively. On the other hand, the nitrate, phosphate, and dissolved oxygen contents of the water show the highest values. The nitrate content ranges from $1.165 \mu \mathrm{mol}$ to $7.81 \mu \mathrm{mol}$ with an average of $4.14 \mu \mathrm{mol}$, while the phosphate content shows a range of $1.774 \mu \mathrm{mol}$ to $8.423 \mu \mathrm{mol}$ with an average of $4.07 \mu \mathrm{mol}$, and total nutrients show a range of $4.202 \mu \mathrm{mol}$ to $11.547 \mu \mathrm{mol}$ with an average of $8.21 \mu \mathrm{mol}$. The dissolved oxygen ranges from $3.886 \mathrm{mg} / \mathrm{L}$ to $7.733 \mathrm{mg} / \mathrm{L}$ with an average $5.34 \mathrm{mg} / \mathrm{L}$ (Table 2 ).

Cluster B (12 samples) comprises of samples from a wider range of the study area $\left(9.5040^{\circ} \mathrm{N}\right.$ to $39.03^{\circ} \mathrm{S}$ latitudes), which mainly falls within the tropical to subtropical zones. This cluster is characterized by the lowest range of all morphological characteristics: average test size (range 225.35-271.00 $\mu \mathrm{m}$; average $247.65 \mu \mathrm{m}$ ), mean proloculus size 
(range 7.07-9.40 $\mu \mathrm{m}$; average $8.34 \mu \mathrm{m}$ ), number of chambers (range 9.38-11.10; average 10.21), and dextral coiling (range 50.00-88.88\%; average 67.32\%). Two ecological parameters, namely, SST (range $15.63-23.85^{\circ} \mathrm{C}$; average $20.55^{\circ} \mathrm{C}$ ) and SSS (range 33.53-35.50 psu; average $35.03 \mathrm{psu}$ ), show the highest ranges. The nutrients and dissolved oxygen showed the lowest ranges. The total nutrient values varied between $1.851 \mu \mathrm{mol}$ and $11.578 \mu \mathrm{mol}$ (average $4.28 \mu \mathrm{mol}$ ), while the dissolved oxygen ranged from $4.431 \mathrm{mg} / \mathrm{L}$ to $5.612 \mathrm{mg} / \mathrm{L}$ (average $4.82 \mathrm{mg} / \mathrm{L}$ ). The nitrate values ranged from $0.3 \mu \mathrm{mol}$ to $9.105 \mu \mathrm{mol}$ (average $1.89 \mu \mathrm{mol}$ ) while phosphate values varied from $1.421 \mu \mathrm{mol}$ to $5.95 \mu \mathrm{mol}$ (average $2.39 \mu \mathrm{mol}$ ). Cluster $\mathrm{B}$ is further subdivided into three subclusters, namely, $\mathrm{B}_{1}, \mathrm{~B}_{2}$, and $\mathrm{B}_{3}$ (Table 2).

Subcluster $B_{1}$ consists of four samples, located within the latitudes of $9.179^{\circ} \mathrm{S}$ and $28.32^{\circ} \mathrm{S}$. This subcluster is characterized by the lowest range of average test size (range 225.35-245.05 $\mu \mathrm{m}$; average $238.03 \mu \mathrm{m}$ ) and dextrality (range $50.00-60.00 \%$; average 54.29\%). On the other hand, it shows the highest range of number of chambers (range 10.0511.10; average 10.54) and moderate range of mean proloculus size (range $7.96-8.64 \mu \mathrm{m}$; average $8.23 \mu \mathrm{m}$ ). In the case of ecological parameters, this cluster shows a lower range of values with the exception of SST and SSS. SST shows the highest values ranging between 19.76 and $22.76^{\circ} \mathrm{C}$ with an average of $21.27^{\circ} \mathrm{C}$. In contrast, SSS ranges moderately within the cluster (range $34.92-35.42 \mathrm{psu}$; average $35.08 \mathrm{psu}$ ). The values of nitrate and phosphate varied from 0.38 to $0.7 \mu \mathrm{mol}$ (average $0.48 \mu \mathrm{mol}$ ) and from 1.421 to $2.245 \mu \mathrm{mol}$ (average $1.68 \mu \mathrm{mol}$ ), respectively, which collectively ranged from 1.851 to $2.945 \mu \mathrm{mol}$ (average $2.17 \mu \mathrm{mol}$ ). Dissolved oxygen ranged from $4.543 \mathrm{mg} / \mathrm{L}$ to $4.936 \mathrm{mg} / \mathrm{L}$, with an average of $4.71 \mathrm{mg} / \mathrm{L}$.

Subcluster $\mathrm{B}_{2}$, represented by four samples, is distributed between latitudes $5.5121^{\circ} \mathrm{N}$ and $39.03^{\circ} \mathrm{S}$. This subcluster is characterized by the lowest range of mean proloculus size (range 7.07-9.15 $\mu \mathrm{m}$; average $7.78 \mu \mathrm{m}$ ), number of chambers (range 9.38-10.11; average 9.73), and the highest range of dextrality (range $75.00-88.88 \%$; average $82.85 \%$ ). On the other hand, it shows a moderate range of average test size (range 58.06-95.65\%; average $82.00 \%$ ) within Cluster B. In the case of ecological parameters, the SSS shows the lowest range (33.53-35.44 psu) with an average of $34.77 \mathrm{psu}$. SST and dissolved oxygen show medium ranges $\left(15.63-23.85^{\circ} \mathrm{C}\right.$, average $21.11^{\circ} \mathrm{C}$ and $4.431-5.612 \mathrm{mg} / \mathrm{L}$, average $4.87 \mathrm{mg} / \mathrm{L}$, resp.). In the case of nutrients, nitrate shows a medium value (range $0.3-1.07 \mu \mathrm{mol}$, average $0.58 \mu \mathrm{mol}$ ), while phosphate shows the highest value (range 1.568-5.95 $\mu \mathrm{mol}$; average $3.10 \mu \mathrm{mol}$ ) within Cluster B; collectively, the nutrient values range from $1.938 \mu \mathrm{mol}$ to $7.02 \mu \mathrm{mol}$ with an average of $3.68 \mu \mathrm{mol}$, which shows a medium value within Cluster B.

Subcluster $\mathrm{B}_{3}$ consists of four samples, located within the latitudes of $9.5045^{\circ} \mathrm{N}$ and $37^{\circ} \mathrm{S}$. This subcluster is characterized by the highest range of average test size (range 259.50-271.00 $\mu \mathrm{m}$; average $264.6 \mu \mathrm{m}$ ) and mean proloculus size (range $8.56-9.40 \mu \mathrm{m}$; average $9.02 \mu \mathrm{m}$ ) within Cluster B. On the other hand, it shows moderate range of number of chambers (range 9.79-10.71; average 10.36) and dextrality (range 53.84-75.00\%; average 64.83\%) within Cluster B. In the case of ecological parameters, this cluster shows the lowest range of SST (16.81-22.08 ${ }^{\circ} \mathrm{C}$; average $\left.19.27^{\circ} \mathrm{C}\right)$ and highest range of SSS (34.94-35.50 psu; average 35.23) within Cluster B. The value of nitrate varies from 0.3 to $9.105 \mu \mathrm{mol}$ (average $4.29 \mu \mathrm{mol})$, which is highest within Cluster B. Though phosphate shows a moderate range $(1.687-4.271 \mu \mathrm{mol}$; average $2.56 \mu \mathrm{mol})$, collective nutrients show the highest range of values (1.987-11.578 $\mu \mathrm{mol}$; average $6.85 \mu \mathrm{mol})$ within Cluster B. Dissolved oxygen shows a range of $4.495 \mathrm{mg} / \mathrm{L}$ to $5.423 \mathrm{mg} / \mathrm{L}$, with an average of $4.90 \mathrm{mg} / \mathrm{L}$, which is highest within Cluster B.

The correlation coefficient between the morphological variations (average test size, proloculus size, number of chambers, and dextrality) and the ecological parameters, namely, SST, SSS, nitrate content, phosphate content, total nutrient (nitrate + phosphate), and dissolved oxygen, was performed (Tables 3(a) and 3(b)). Some correlation was found moderately correlatable, namely, test size-SST, test size-nitrate (hence total nutrient), test size-dissolved oxygen, number of chambers-dissolved oxygen, proloculus size-SST, proloculus size-nitrate (hence total nutrient), and proloculus size-dissolved oxygen.

\section{Discussion and Conclusion}

The foraminiferal data have been subjected so far to statistical analysis, namely, cluster analysis in different geographical regions and for various purposes [36-46].

G. bulloides is abundant in high southern latitude water masses and is at its peak in high northern latitudes, low latitude upwelling regions, and nutrient-rich environments [47-50]. In this study, cluster analysis on the morphological characteristics of $G$. bulloides is used to differentiate different water masses depending more on ecological parameters than on latitudinal gradients. In general, two major clusters (Clusters A and B) show that morphological characteristics are directly correlated to nutrients and dissolved oxygen of the ambient water mass and inversely correlated to sea surface temperature and sea surface salinity. From the combined results of all subclusters, it was observed that average test size depends directly on nitrate values and dissolved oxygen content of the ambient environment and is inversely related to the temperature. The average size of $G$. bulloides in Cluster A $(357.33 \mu \mathrm{m})$ is greater than that in Cluster B $(247.65 \mu \mathrm{m})$. Comparing the nitrate value, dissolved oxygen content, and temperature, we found that the average nitrate value and dissolved oxygen value of surface water in Cluster A (4.14 psu and $5.34 \mathrm{mg} / \mathrm{L}$, resp.) are much higher than those in Cluster B (1.89 psu and $4.82 \mathrm{mg} / \mathrm{L}$, resp.). In case of the three subclusters of Cluster B, the same trend was also observed (Table 1). Bé et al. [51] and Hecht [52] pioneered the study of the ecological influence on the adult test size of planktic foraminifers. In the North Atlantic region, "environmental optima" were defined for temperature and salinities for many planktonic species including G. bulloides [52]. Largest sizes of the same species were reported in the Indian Ocean at temperatures around $6-7^{\circ} \mathrm{C}[53,54]$. A positive correlation between general size and the frequencies of $G$. bulloides suggests that optimum growth occurs in areas of optimum environmental conditions rather than in more marginal environments where delayed 


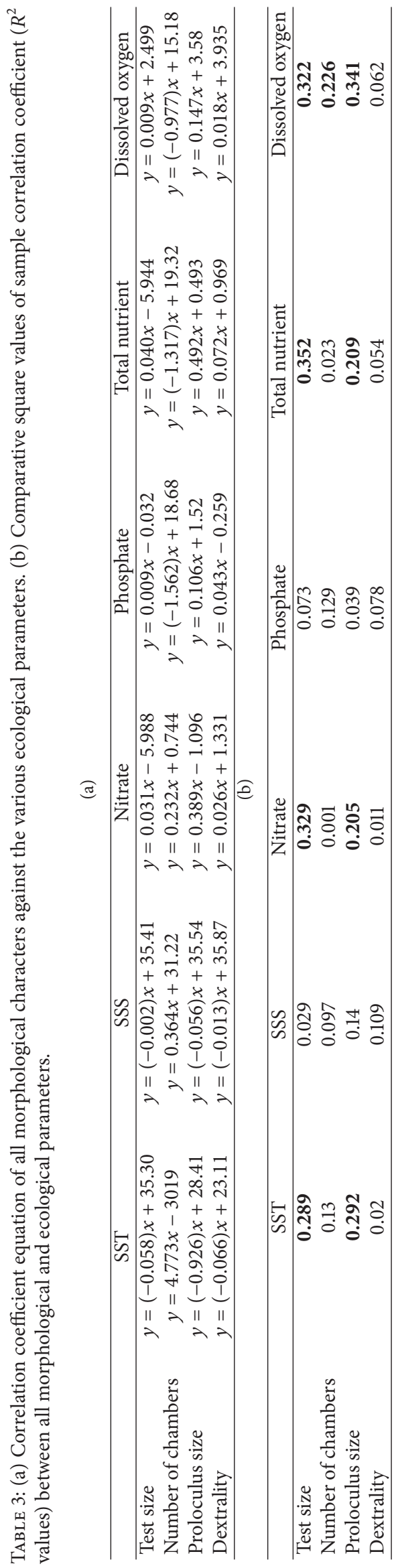


reproduction (and hence greater size) might have occurred [53]. The upwelling assemblage, predominated by the species G. bulloides, has an affinity to high nutrients, because fertility is the defining characteristic for these assemblages [55].

Mean proloculus size (MPS) increases with the increase in SSS. In all subclusters under Cluster B, the average MPS shows a direct relation with the average SSS. Moreover, in our study, it is recorded that an increase in phosphate leads to a rise in dextrality and number of chambers. In Cluster A, the average dextrality and number of chambers show higher values $(70.21 \%$ and 10.23 , resp.) than those in Cluster B (67.32\% and 10.21, resp.), which shows a direct relationship with the higher average phosphate value in Cluster A (4.07 psu) and lower value in Cluster B (2.39 psu). The dextrality is also showing an inverse dependency on the average SST. Cluster A shows higher average dextrality (70.31\%) with lower average SST $\left(14.61^{\circ} \mathrm{C}\right)$, whereas Cluster B shows lower average dextrality $(67.32 \%)$ with higher average SST $\left(20.55^{\circ} \mathrm{C}\right)$. An association between surface-water temperatures and coiling direction in living $G$. bulloides was reported from the southwestern Atlantic Ocean [56]. Malmgren and Kennett [53] observed a distinct relationship between the average surface-water temperature and coiling direction of G. bulloides. However, in both Antarctic Ocean and Indian Ocean, the surface-water temperature and the percentage of sinistral specimens are significantly negatively correlated.

Morphologically defined species of marine plankton often harbor a considerable level of cryptic diversity [57]. The results of present study are purely based on the cluster analyses of the morphological features of planktic species Globigerina bulloides on the assumption that each morphospecies of planktonic Foraminifera represents a genetically continuous species with a unique habitat. However, the possibility of having cryptic species in the species level population in the study material may not be ruled out completely. No doubt hidden genetic diversity among modern planktonic Foraminifera has significant repercussions on paleoproxies derived from their fossil shells. Nevertheless, Kucera and Darling [58] have compiled the genetic diversity and found 33 cryptic genetic types in 9 out of the 22 sequenced morphospecies of modern planktonic Foraminifera, implying that the total number of cryptic genetic types per morphospecies is not large and that most genetic types show a nonrandom pattern of distribution in the oceans [58]. Furthermore, Morard et al. [59] also pointed out that the cryptic genetic species of planktonic Foraminifera often exhibit narrower biogeographic distributions and ecological preferences than the respective morphospecies. In theory, it should therefore be possible to improve the resolution of the paleoceanographic reconstructions based on sediment assemblages of these species. Since many morphospecies show cosmopolitan distribution, an understanding of biogeographic and evolutionary processes at the level of genetic diversity requires global sampling [57]. Such an approach is beyond the scope of the present study.

Though the inferences drawn in the present study based on Q-mode cluster analysis clearly establish a correspondence between the ecological parameters of the ambient water masses and the morphological variables of the planktic foraminiferal species $G$. bulloides, more transects covering a wide geographical region need to be covered for arriving at a clearer conclusion.

\section{Conflict of Interests}

The authors declare that there is no conflict of interests regarding the publication of this paper.

\section{Acknowledgments}

The authors are grateful to the Director, Birbal Sahni, Institute of Paleobotany, Lucknow, and Ministry of Earth Science for providing permission to publish this paper. The authors are thankful to Ms. Rosyta Afonso for processing the samples. The authors are also thankful to Ms. Neelam Pereira for linguistic upgrade of this paper.

\section{References}

[1] K. B. Lewis and C. Jenkins, "Geographical variation of Nonionellina flemingi," Micropaleontology, vol. 15, no. 1, pp. 1-12, 1969.

[2] A. D. Hecht, "Intraspecific variation in Recent populations of Globigerinoides ruber and Globigerinoides trilobus and their application to paleoenvironmental analysis," Journal of Paleontology, vol. 48, pp. 1217-1234, 1974.

[3] J. P. Kennett, "Phenotypic variation in some recent and late Cenozoic planktonic foraminifera," in Foraminifera, R. H. Hedley and C. G. Adams, Eds., pp. 111-170, Academic Press, New York, NY, USA, 1976.

[4] A. W. H. Bé and D. S. Tolderlund, "Distribution and ecology of living planktonic foraminifera in surface waters of the Atlantic and Indian oceans," in Micropaleontology of Marine Bottom Sediments, B. M. Funnell and W. R. Riedel, Eds., pp. 105-149, Cambridge University Press, Cambridge, UK, 1971.

[5] A. W. H. Bé and W. H. Hutson, "Ecology of planktonic foraminifera and biogeographic patterns of life and fossil assemblages in the Indian Ocean," Micropaleontology, vol. 23, pp. 369-414, 1977.

[6] W. B. Curry, D. R. Ostermann, M. V. S. Gupta, and V. Ittekkot, "Foraminiferal production and monsoonal upwelling in the Arabian Sea: evidence from sediment traps," in Upwelling Systems: Evolution Since the Early Miocene, C. P. Summerhays, W. L. Prell, and K. C. Emeis, Eds., Geological Society Special Publication No. 64, pp. 93-106, The Geological Society, London, UK, 1992.

[7] W. L. Prell, D. W. Murray, S. C. Clemens, and D. M. Anderson, "Evolution and variability of the Indian Ocean summer monsoon: evidence from the Western Arabian sea drilling program," in Synthesis of Results from Scientific Drilling in the Indian Ocean, Geophysical Monograph no. 70, 1992.

[8] D. M. Anderson and W. L. Prell, "A 300 kyr record of upwelling off Oman during the late Quaternary: evidence of the Asian Southwest monsoon," Paleoceanography, vol. 8, no. 2, pp. 193208, 1993.

[9] P. D. Naidu and B. A. Malmgren, "Monsoon upwelling effects on test size of some planktonic foraminiferal species from the Oman Margin, Arabian Sea," Paleoceanography, vol. 10, no. 1, pp. 117-122, 1995. 
[10] P. D. Naidu and B. A. Malmgren, "Relationship between late quaternary upwelling history and coiling properties of Neogloboquadrina pachyderma and Globigerina bulloides in the Arabian Sea," Journal of Foraminiferal Research, vol. 26, no. 1, pp. 64-70, 1996.

[11] S.-H. Conan and G. J. A. Brummer, "Fluxes of planktic foraminifera in response to monsoonal upwelling on the Somalia Basin margin," Deep-Sea Research Part II: Topical Studies in Oceanography, vol. 47, no. 9-11, pp. 2207-2227, 2000.

[12] L. R. Sautter and R. C. Thunell, "Seasonal succession of planktonic foraminifera: results from a four- year time-series sediment trap experiment in the Northeast Pacific," Journal of Foraminiferal Research, vol. 19, no. 4, pp. 253-267, 1989.

[13] L. R. Sautter and C. Sancetta, "Seasonal associations of phytoplankton and planktic foraminifera in an upwelling region and their contribution to the seafloor," Marine Micropaleontology, vol. 18, no. 4, pp. 263-278, 1992.

[14] E. Bard, M. Arnold, P. Maurice, J. Duprat, J. Moyes, and J.-C. Duplessy, "Retreat velocity of the North Atlantic polar front during the last deglaciation determined by $14 \mathrm{C}$ accelerator mass spectrometry," Nature, vol. 328, no. 6133, pp. 791-794, 1988.

[15] N. Kallel, L. D. Labeyrie, A. Juillet-Leclerc, and J.-C. Duplessy, "A deep hydrological front between intermediate and deepwafpr , masses in the glacial Indian Ocean," Nature, vol. 333, no. 6174 , pp. $651-655,1988$.

[16] L. R. Sautter and R. C. Thunell, "Planktonic foraminiferal response to upwelling and seasonal hydrographic conditions: sediment trap results from San Pedro Basin, Southern California Bight," Journal of Foraminiferal Research, vol. 21, no. 4, pp. 347-363, 1991.

[17] S. Chiyonobu, Y. Mori, and M. Oda, "Reconstruction of paleoceanographic conditions in the northwestern Pacific Ocean over the last 500kyr based on calcareous nannofossil and planktic foraminiferal assemblages," Marine Micropaleontology, vol. 96-97, pp. 29-37, 2012.

[18] N. V. Belyaeva, "Distribution of planktonic Foraminifera in the water and on the ocean floor in the Indian Ocean," Trudy Instituta Okeanologii Akademiia Nauk SSSR, vol. 68, pp. 12-83, 1964.

[19] D. G. Blair, "The distribution of planktonic Foraminifera in deep-sea cores from the Southern Ocean, Antarctica," Department of Geology, Florida State University, Contribution no. 10, 1965.

[20] E. Boltovskoy, "Living planktonic foraminifera at the $90^{\circ} \mathrm{E}$ meridian from the equator Lo the Antarctic," Micropaleontology, vol. 15, pp. 237-255, 1969.

[21] O. L. Bandy, "Variations in Globigerina bulloides d'Orbigny as indices of water masses," Antarctic Journal, vol. 7, pp. 194-195, 1972.

[22] T. Ichiye, "Indian ocean: oceanography," in The Encyclopedia of Oceanography, R. W. Fairbridge, Ed., pp. 383-396, Van Nostrand-Reinhold, New York, NY, USA, 1962.

[23] K. Wyrtki, Oceanographic Atlas of the International Indian Ocean Expedition, National Science Foundation, Washington, DC, USA, 1971.

[24] A. L. Gordon, "Introduction: physical oceanography of the southeast Indian Ocean," in Antarctic Oceanology, The Australian-New Zealand Sector, D. E. Hayes, Ed., Antarctic Research Series 19, pp. 3-9, American Geophysical Union, Washington, DC, USA, 1972.

[25] G. Schott, Geographic des Atlantischen Ozeans, Boysen, Hamburg, Germany, 1942.
[26] N. Anilkumar, A. J. Luis, Y. K. Somayajulu et al., "Fronts, water masses and heat content variability in the Western Indian sector of the Southern Ocean during austral summer 2004," Journal of Marine Systems, vol. 63, no. 1-2, pp. 20-34, 2006.

[27] A. L. Gordon, "Oceanography-the brawniest retroflection," Nature, vol. 421, pp. 904-905, 2003.

[28] Y.-H. Park, E. Charriaud, and M. Fieux, "Thermohaline structure of the Antarctic surface water/Winter Water in the Indian sector of the Southern Ocean," Journal of Marine Systems, vol. 17, no. 1-4, pp. 5-23, 1998.

[29] W. D. Nowlin Jr. and J. M. Klinck, "The physics of the antarctic circumpolar current," Reviews of Geophysics, vol. 24, pp. 469491, 1986.

[30] J. M. Toole and B. A. Warren, "A hydrographic section across the subtropical South Indian Ocean," Deep-Sea Research Part I, vol. 40, no. 10, pp. 1973-2019, 1993.

[31] B. A. Warren, "Indian Ocean, Deep circulation," in McGraw Hill Yearbook of Science and Technology, pp. 227-229, McGraw-Hill, New York, NY, USA, 1980.

[32] M. E. Conkright, S. Levitus, and T. Boyer, World Ocean Atlas 1994, Vol. 1: Nutrients. NOAA Atlas NESDIS 1, U.S. Government Printing Office, Washington, DC, USA, 1994.

[33] S. Levitus and T. Boyer, World Ocean Atlas 1994, Vol. 2: Oxygen, NOAA Atlas NESDIS 2, U.S. Government Printing Office, Washington, DC, USA, 1994.

[34] S. Levitus and T. Boyer, World Ocean Atlas 1994, Volume 4: Temperature, NOAA Atlas NESDIS 4, Printing Office, Washington, DC, USA, 1994.

[35] S. Levitus, R. Burgett, and T. Boyer, World Ocean Atlas 1994, Volume 3: Salinity, NOAA Atlas NESDIS 3, U.S. Government Printing Office, Washington, DC, USA, 1994.

[36] R. L. Kausler, "Quantitative re-evaluation of ecology and distribution of Recent foraminifera and ostracoda of Todos Santos Bay, Baja California, Mexico," Contrib. Paper no. 10, The University of Kansas Paleontological Institute, 1966.

[37] J. F. Mellow and M. A. Buzas, "An application of cluster analysis as a method to determining biofacies," Journal of Paleontology, vol. 42, pp. 747-758, 1968.

[38] H. Ujiie and K. Nagase, "Cluster analysis of living plankyonic foraminifera from the southeastern Indian Ocean," in Proceedings of the 2nd International Planktonic Conference, pp. 12511258, Rome, Italy, 1971.

[39] J. W. Valentine and R. G. Peddicord, "Evolution of fossil assemblages by cluster analysis," Journal of Pacific Shelf. Limnology and Oceanography, vol. 11, pp. 198-211, 1967.

[40] H. Drinia, A. Antonarakou, and N. Tsaparas, "Diversity and abundance trends of benthic foraminifera from the southern part of the Iraklion Basin, Central Crete," Bulletin of the Geological Society of Greece, vol. 36, pp. 772-781, 2004.

[41] R. Nigam and J. S. Sarupria, "Cluster analysis and ecology of living benthonic foraminifera from the inner shelf off Ratnagiri, West Coast, India," Journal of the Geological Society of India, vol. 22, pp. 175-180, 1981.

[42] A. N. Reddy and K. R. Reddy, "Cluster analysis and distribution of recent foraminifera, Araniar River estuary, Tamil Nadu, India," Journal of the Geological Society of India, vol. 33, pp. 7681, 1989.

[43] W. T. Coulbourn, "Relationship between the distribution of foraminifera and geologic structures of the Arctic Bight, South America," Journal of Paleontology, vol. 54, pp. 696-718, 1980. 
[44] Y. Ujiié, H. Ujiié, A. Taira, T. Nakamura, and K. Oguri, "Spatial and temporal variability of surface water in the Kuroshio source region, Pacific Ocean, over the past 21,000 years: evidence from planktonic foraminifera," Marine Micropaleontology, vol. 49, no. 4, pp. 335-364, 2003.

[45] E. Taldenkova, H. A. Bauch, A. Stepanova et al., "Benthic and planktic community changes at the North Siberian margin in response to Atlantic water mass variability since last deglacial times," Marine Micropaleontology, vol. 96-97, pp. 13-28, 2012.

[46] T. L. Rasmussen and E. Thomsen, "Changes in planktic foraminiferal faunas, temperature and salinity in the Gulf Stream during the last 30,000 years: influence of meltwater via the Mississippi River," Quaternary Science Reviews, vol. 33, pp. 4254, 2012.

[47] J. C. Duplessy, A. W. H. Bé, and P. L. Blanc, "Oxygen and carbon isotopic composition and biogeographic distribution of planktonic foraminifera in the Indian Ocean," Palaeogeography, Palaeoclimatology, Palaeoecology, vol. 33, pp. 9-46, 1981.

[48] C. Hemleben, M. Spindler, and O. R. Anderson, Modern Planktonic Foraminifera, Springer, New York, NY, USA, 1989.

[49] J. Thiede, "Skeletal plankton and nekton in upwelling water masses off northwestern south America and northwest Africa," in Coastal Upwelling: Its Sediment Record, E. Suess and J. Thiede, Eds., pp. 183-207, Plenum Press, New York, NY, USA, 1983.

[50] B. Zhang, "Living planktonic foraminifera from eastern Arabian Sea," Deep Sea Research, vol. 12, pp. 789-798, 1985.

[51] A. W. H. Bé, S. M. Harrison, and L. Lott, "Orbulina universa d'Orbigny in the Indian Ocean," Micropaleontology, vol. 19, pp. 150-192, 1973.

[52] A. D. Hecht, "An ecologic model for test size variation recent planktonic foraminifera: application to the fossil record," Journal of Foraminiferal Research, vol. 6, pp. 295-311, 1976.

[53] B. Malmgren and J. P. Kennett, "Biometric analysis of phenotypic variation in Recent Globigerina bulloides d'Orbigny in the Southern Indian Ocean," Marine Micropaleontology, vol. 1, pp. 3-25, 1976.

[54] D. N. Schmidt, S. Renaud, J. Bollmann, R. Schiebel, and H. R. Thierstein, "Size distribution of Holocene planktic foraminifer assemblages: biogeography, ecology and adaptation," Marine Micropaleontology, vol. 50, no. 3-4, pp. 319-338, 2004.

[55] R. Schiebel, J. Bijma, and C. Hemleben, "Population dynamics of the planktic foraminifer Globigerina hulloides from the Eastern North Atlantic," Deep-Sea Research Part I: Oceanographic Research Papers, vol. 44, no. 9-10, pp. 1701-1713, 1997.

[56] E. Boltovskoy, "Note on the determination of absolute surface water paleotemperature by means of the foraminifer Globigerina bulloides d'Orbigny," Paläontologische Zeitschrift, vol. 47, no. 3-4, pp. 152-155, 1973.

[57] A. K. M. Weiner, M. F. G. Weinkauf, A. Kurasawa, K. F. Darling, M. Kucera, and G. W. Grimm, "Phylogeography of the tropical planktonic foraminifera lineage Globigerinella reveals isolation inconsistent with passive dispersal by ocean currents," PLoS ONE, vol. 9, no. 3, Article ID e92148, 2014.

[58] M. Kucera and K. F. Darling, "Cryptic species of planktonic foraminifera: their effect on palaeoceanographic reconstructions," Philosophical Transactions of the Royal Society A: Mathematical, Physical and Engineering Sciences, vol. 360, no. 1793, pp. 695-718, 2002.

[59] R. Morard, F. Quillévéré, G. Escarguel, T. de Garidel-Thoron, C. de Vargas, and M. Kucera, "Ecological modeling of the temperature dependence of cryptic species of planktonic Foraminifera in the Southern Hemisphere," Palaeogeography, Palaeoclimatology, Palaeoecology, vol. 391, pp. 13-33, 2013. 

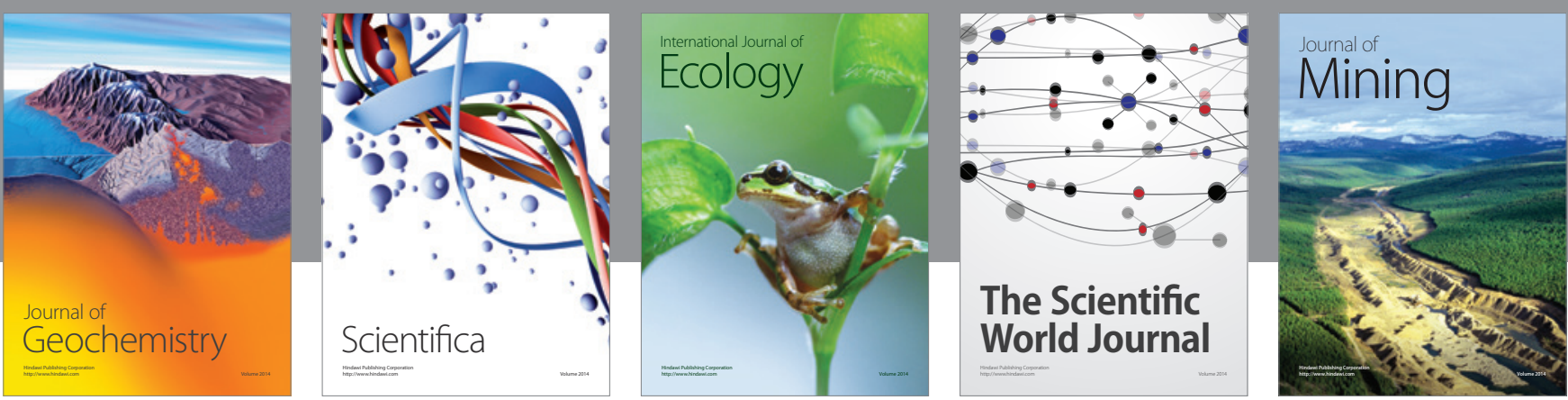

The Scientific World Journal
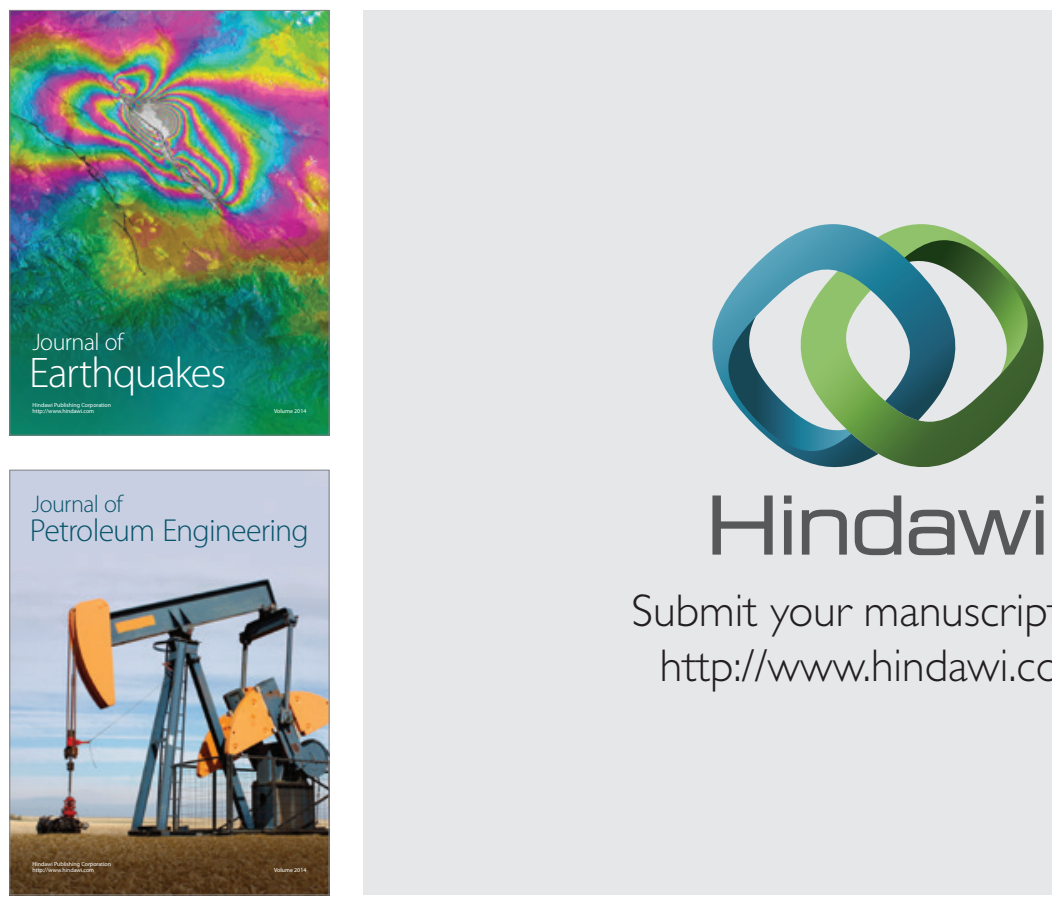

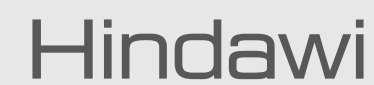

Submit your manuscripts at

http://www.hindawi.com
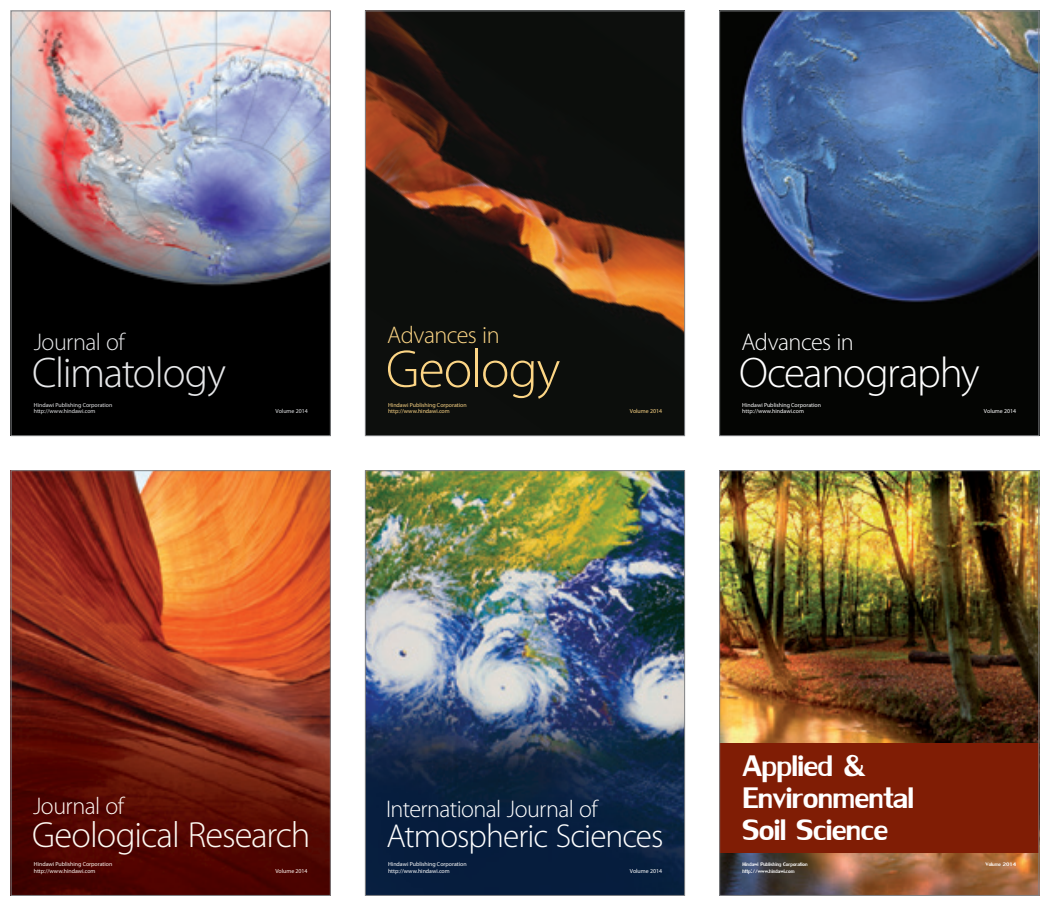
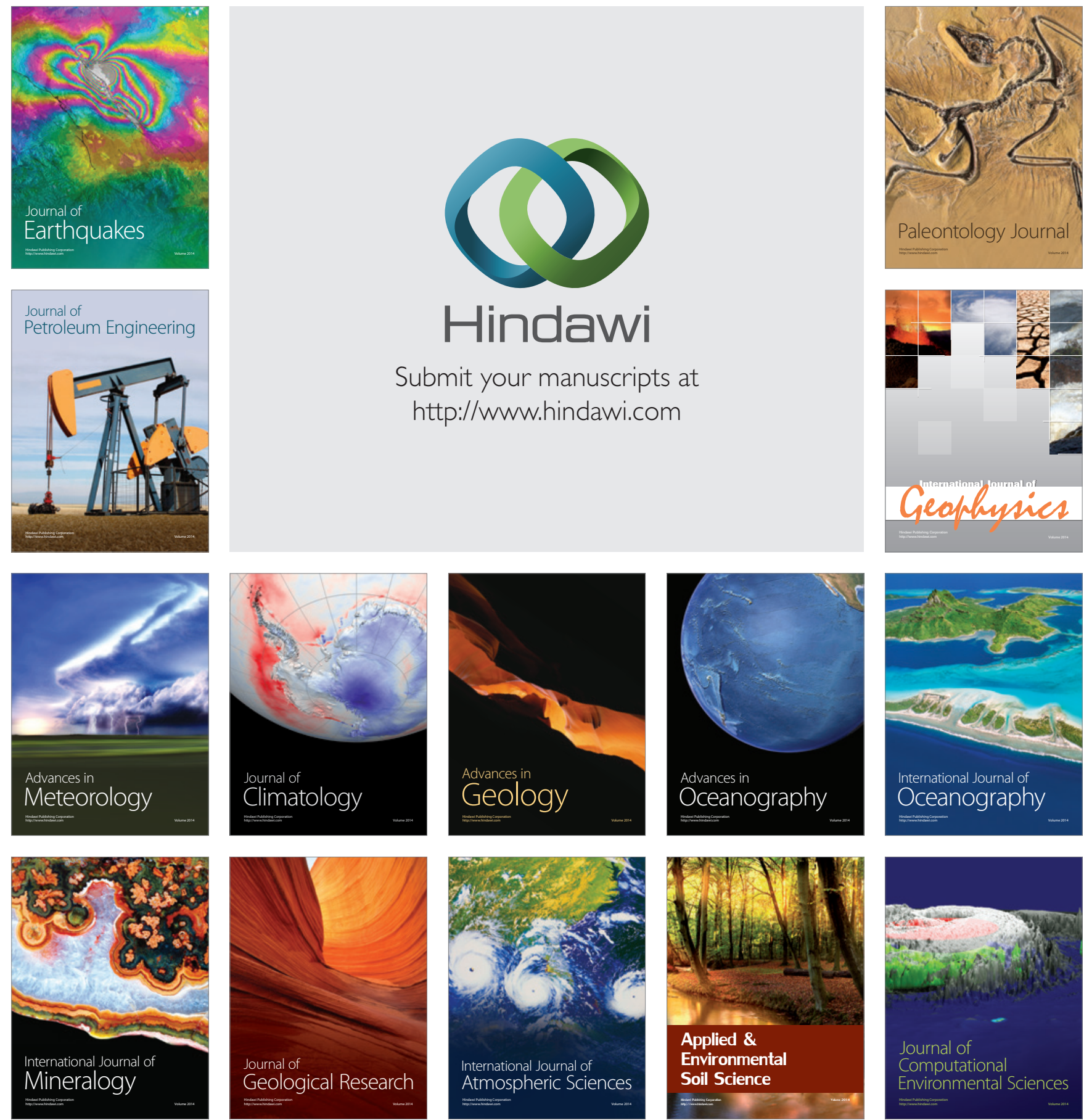